\title{
High-Temperature Oxidation Properties and Microstructural Evolution of Nanostructure Fe-Cr-Al ODS Alloys
}

\author{
Zhengyuan Li, Lijia Chen *, Haoyu Zhang (1) and Siyu Liu \\ School of Materials Science and Engineering, Shenyang University of Technology, Shenyang 110870, China; \\ zhengyli@sut.edu.cn (Z.L.); zhanghaoyu@sut.edu.cn (H.Z.); lsiyuu@outlook.com (S.L.) \\ * Correspondence: chenlijia@sut.edu.cn; Tel.: +86-(24)-2549-6253
}

\begin{abstract}
The oxidation behavior and microstructural evolution of the nanostructure of Fe-Cr-Al oxide dispersion strengthened (ODS) alloys prepared by spark plasma sintering were investigated by high-temperature oxidation experiments in air at $1200^{\circ} \mathrm{C}$ for $100 \mathrm{~h}$. The formation of $\mathrm{Al}_{2} \mathrm{O}_{3}$ scale was observed by X-ray diffraction (XRD) and scanning electron microscopy (SEM) with energy-dispersive $\mathrm{X}$-ray spectroscopy (EDS) line scans. The oxidation rate of Fe-Cr-Al ODS alloys is lower than that of conventional Fe-Cr-Al alloys, and the oxide layer formed on the $\mathrm{Fe}-\mathrm{Cr}-\mathrm{Al}$ alloy appeared loose and cracked, whereas the oxide layer formed on the Fe-Cr-Al ODS alloys was adherent and flat. This is due to the high density of dispersed nano-oxides hindering the diffusion of Al element and the formation of vacancies caused by them. In addition, the nano-oxides could also adhere to the oxide layer. Besides, the microstructure of the Fe-Cr-Al ODS alloy had excellent stability during high-temperature oxidation.
\end{abstract}

Keywords: ODS alloys; spark plasma sintering; high-temperature oxidation; microstructure; diffusion

check for updates

Citation: Li, Z.; Chen, L.; Zhang, H.; Liu, S. High-Temperature Oxidation Properties and Microstructural Evolution of Nanostructure Fe-Cr-Al ODS Alloys. Materials 2021, 14, 526. https://doi.org/10.3390/ma14030526

Received: 8 December 2020

Accepted: 18 January 2021

Published: 22 January 2021

Publisher's Note: MDPI stays neutral with regard to jurisdictional claims in published maps and institutional affiliations.

Copyright: (c) 2021 by the authors. Licensee MDPI, Basel, Switzerland. This article is an open access article distributed under the terms and conditions of the Creative Commons Attribution (CC BY) license (https:// creativecommons.org/licenses/by/ $4.0 /)$.

\section{Introduction}

Fe-Cr-Al alloys are considered one of the Accident Tolerant Fuel (ATF) technologies for future advanced fission [1-3]. This material has excellent resistance to high-temperature oxidation due to the formation of alumina film on the surface. Various research has reported that $\mathrm{Fe}-\mathrm{Cr}-\mathrm{Al}$ alloys have a lower oxidation rate and heat-release rate in hightemperature dry air and steam environments than conventional $\mathrm{Zr}$ alloys $[4,5]$. Therefore, the application of $\mathrm{Fe}-\mathrm{Cr}-\mathrm{Al}$ alloys can improve the safety margin of reactor operation.

The high-temperature oxidation resistance of $\mathrm{Fe}-\mathrm{Cr}$ - $\mathrm{Al}$ alloys is significantly affected by the content of $\mathrm{Cr}$ and $\mathrm{Al}$ elements. The $\mathrm{Cr}$ and $\mathrm{Al}$ content can be balanced between corrosion resistance, mechanical properties and radiation embrittlement. Usually, the $\mathrm{Cr}$ content ranges from 9 to $16 \mathrm{wt} . \%$, and the $\mathrm{Al}$ content is around $4 \mathrm{wt} . \%$ [6-9]. In order to increase the high-temperature strength, an oxide dispersion strengthening (ODS) phase $\left(\mathrm{Y}_{2} \mathrm{O}_{3}\right)$ is added to $\mathrm{Fe}-\mathrm{Cr}-\mathrm{Al}$ alloys $[10,11]$. However, only adding $\mathrm{Y}_{2} \mathrm{O}_{3}$ alone will lead to a limited increase in the strength as a result of the formation of coarse $\mathrm{Y}$-Al-O particles. To conquer this issue, $\mathrm{Zr}$ element is used to form finer $\mathrm{Y}-\mathrm{Zr}$-O particles due to the higher binding energies of $\mathrm{Y}-\mathrm{Zr}-\mathrm{O}$ than those of $\mathrm{Y}-\mathrm{Al}-\mathrm{O}$. Thus, the combined addition of $\mathrm{Y}_{2} \mathrm{O}_{3}$ and $\mathrm{Zr}$ elements can significantly improve the high-temperature strength of the $\mathrm{Fe}-\mathrm{Cr}-\mathrm{Al}$ alloy [12-14].

For the Fe-Cr-Al base ODS alloy, used as ATF cladding material, the high-temperature oxidation resistance mainly comes from the formation of $\mathrm{Al}_{2} \mathrm{O}_{3}$, which is uniquely influenced by the nanodispersion and the addition of reactive elements such as $\mathrm{Y}$, Ti and $\mathrm{Zr}[4,15,16]$. Merceron et al. [17] compared the oxidation behavior of the Fe-Cr-Al-ODS alloy (MA 956) and Fe-Cr-Al alloy. It is noted that both alloys exhibited excellent oxidation stability at $1200^{\circ} \mathrm{C}$ in air. Lipkina et al. [18] measured the mass change over time during high-temperature oxidation by Thermo-Gravimetric Analysis (TGA) in air and steam. As Lipkina et al. suggested, the parabolic oxidation rates in air and steam are almost the same. 
Maeda et al. [19] studied the influence of $\mathrm{Zr}$ on the oxidation of Fe-Cr-Al ODS in air and steam between 1200 and $1500{ }^{\circ} \mathrm{C}$. The results show that proper $\mathrm{Zr}$ and $\mathrm{O}$ ratios decelerate the oxidation rate. In addition, Unocic [16], Lipkina [18] and Maeda [19] suggested that there is little difference in the oxidation behavior of Fe-Cr-Al ODS alloys in air and water moist environments.

It is well known that many factors can significantly affect the oxidation behavior of the alloy, such as changes in the grain size, precipitation distribution and dislocation density, and atomic diffusion [17]. Regarding the Fe-Cr-Al ODS alloy, in addition to the alloy composition, the fine nano-oxides also play a significant role in the high-temperature oxidation behavior of the Fe-Cr-Al ODS alloy. During the high-temperature oxidation process, the special microstructure of the ODS alloy also evolves. However, there are limited reports focusing on the effect of ODS alloy microstructural evolution on high-temperature oxidation behavior. This work studied the high-temperature oxidation kinetics of the Fe-Cr-Al ODS alloy with $\mathrm{Zr}$ addition in air. The aim was to investigate the influence of the Fe-Cr-Al ODS alloy microstructure's (especially the fine nano-oxides) evolution on the oxidation behavior.

\section{Materials and Methods}

High-purity $\mathrm{Fe}, \mathrm{Cr}, \mathrm{Al}, \mathrm{Ti}, \mathrm{Zr}$ and $\mathrm{Y}_{2} \mathrm{O}_{3}$ powders were milled in a nominal composition of Fe-15Cr-4.5Al-0.3Ti-0.3Zr- $0.3 \mathrm{Y}_{2} \mathrm{O}_{3}$ (wt.\%). The $\mathrm{Y}_{2} \mathrm{O}_{3}$ content was at two levels: 0 and $0.3 \mathrm{wt} . \%$. Ball milling was carried out in a Fritsch Pulverisette 5 high-energy planetary mill (Fritsch, Idar-Oberstein, Germany) at $260 \mathrm{rpm}$ for $50 \mathrm{~h}$ with a ball-to-powder mass ratio of 10:1 in an argon atmosphere. Spark plasma sintering (SPS) technology (SPS-3.20MK-V, Sumitomo, Tokyo, Japan) was used for subsequent heat curing. The sintering parameters were a $100{ }^{\circ} \mathrm{C}$ heating rate to $950{ }^{\circ} \mathrm{C}$ for $10 \mathrm{~min}$ under a pressure of $40 \mathrm{MPa}$ in a vacuum with a pulsed direct current consisting of a $12 \mathrm{~ms}$ power pulse and a $2 \mathrm{~ms}$ intermission between pulses. The consolidated specimens were $30 \mathrm{~mm}$ in diameter and $\sim 7 \mathrm{~mm}$ in thickness. The measured compositions of the consolidated alloys are given in Table 1. The density of the sample after SPS sintering was $97.4 \% \pm 0.2 \%$, and research on the microstructure and properties of ODS alloys with similar compositions prepared by SPS is shown in preliminary reports [20-22].

Table 1. The measured chemical compositions of the oxide dispersion strengthening (ODS) alloys (wt.\%).

\begin{tabular}{ccccccc}
\hline Material & $\mathrm{Fe}$ & $\mathrm{Cr}$ & $\mathrm{Al}$ & $\mathrm{Ti}$ & $\mathrm{Zr}$ & $\mathrm{Y}_{2} \mathrm{O}_{3}$ \\
\hline Fe-Cr-Al & Bal. & 14.6 & 4.3 & 0.27 & - & - \\
Fe-Cr-Al & Bal. & 14.8 & 4.2 & 0.28 & 0.28 & 0.31 \\
ODS & & & & & & \\
\hline
\end{tabular}

The specimens for high-temperature oxidation were cut into $10 \times 5 \times 3 \mathrm{~mm}^{3}$ pieces by wire electrical discharge machining, and then were ground with grit size 400, 800, 1000, 2000 and $3000 \mathrm{SiC}$ paper and finished with $1 \mu \mathrm{m}$ diamond polishing paste to obtain a mirror surface. The specimens were then placed in an alumina crucible and subjected to high-temperature oxidation tests in a furnace at $1200^{\circ} \mathrm{C}$ for $100 \mathrm{~h}$ (included $100 \mathrm{~h}$ ) with a heating rate of $10^{\circ} \mathrm{C} / \mathrm{min}$. In the high-temperature oxidation experiment, only one sample was tested. The samples were taken out of the furnace at different times, weighed when they had cooled to room temperature in air, and then placed in the furnace.

The specimens after high-temperature oxidation were investigated by X'Pert Pro X-ray diffraction (XRD, PANalytical B.V., Almelo, The Netherlands) with a scanning speed of $4^{\circ} / \mathrm{min}$ and a $\mathrm{Cu} \mathrm{K} \alpha$ target. The composition of the oxide layer was determined with a JEOL 6500F scanning electron microscope (SEM, JEOL, Tokyo, Japan) with Energy Dispersive X-ray Spectroscopy (EDS). Electron backscattered diffraction (EBSD) was used to observe the changes in grain size. The EBSD samples were prepared by mechanical polishing and, subsequently, electro-chemical etching in a solution of $20 \% \mathrm{HClO}_{4}+80 \% \mathrm{CH}_{3} \mathrm{CH}_{2} \mathrm{OH}$ 
under $20 \mathrm{~V}$ at room temperature for about one minute. A JEOL $2100 \mathrm{~F}$ transmission electron microscope (TEM, JEOL, Tokyo, Japan) was employed to analyze the evolution of nano-oxides. The TEM specimens were mechanically polished and etched using $4 \%$ nitric acid-ethanol. The etched surfaces were coated with a carbon film with a K950X coater (Quorum, Hertfordshire, England), and then chemically etched again in a similar acid solution, and the floating carbon films were retrieved on $\varnothing 3 \mathrm{~mm}$ copper meshes.

\section{Results}

\subsection{High-Temperature Oxidation}

Figure 1 shows the mass gain measurements of the $\mathrm{Fe}-\mathrm{Cr}-\mathrm{Al}$ alloy and $\mathrm{Fe}-\mathrm{Cr}-\mathrm{Al}$ ODS alloy oxidized in air at $1200^{\circ} \mathrm{C}$. Although only one sample was measured, reducing the reliability, it still showed obvious regularity, which indicates that the Fe-Cr-Al ODS specimen had better oxidation resistance, which suggests that $\mathrm{Y}_{2} \mathrm{O}_{3}$ addition decelerates oxidation under this condition.
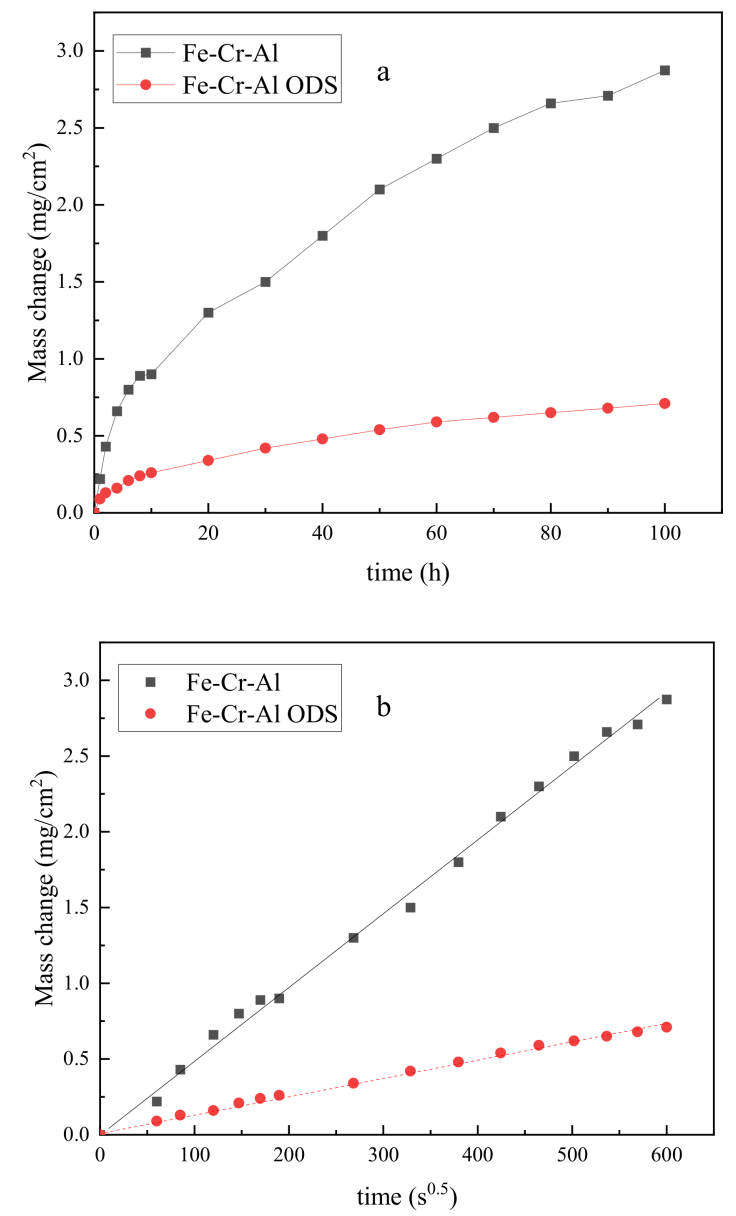

Figure 1. (a) Mass change curves and (b) the linearity between $\mathrm{mg} / \mathrm{cm}^{2}$ and $\mathrm{s}^{0.5}$ of studied alloys in air at $1200{ }^{\circ} \mathrm{C}$.

The surface oxidation morphologies of the Fe-Cr-Al alloy and Fe-Cr-Al ODS alloy are shown in Figure 2. The oxide film of the $\mathrm{Fe}-\mathrm{Cr}-\mathrm{Al}$ alloy was loose and uneven, and there were a lot of pores on the oxide film. However, a compact and smooth oxide film was formed on the surface of the Fe-Cr-Al ODS alloy. 

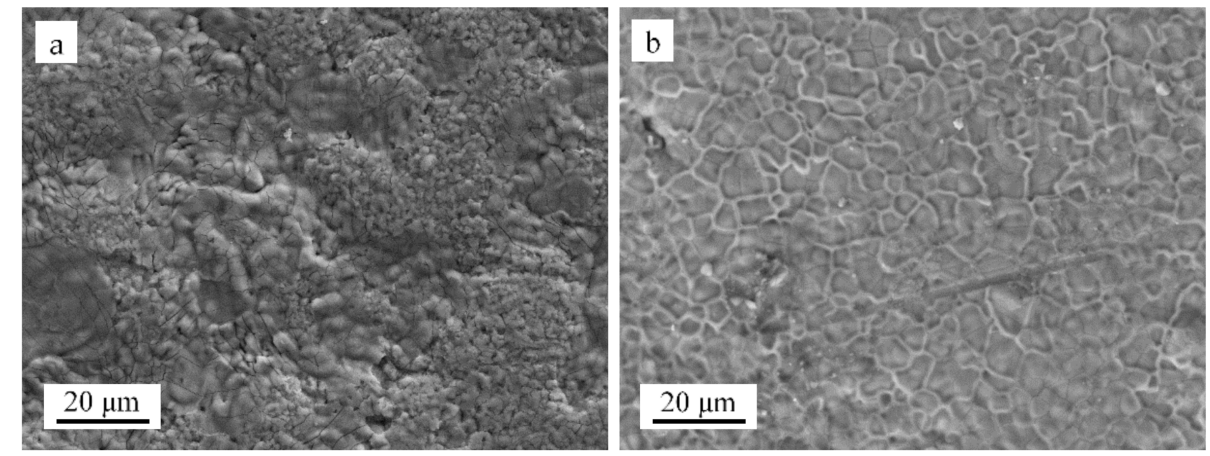

Figure 2. Surface SEM photographs of two alloys oxidized in air at $1200{ }^{\circ} \mathrm{C}$ for $100 \mathrm{~h}$ : (a) Fe-Cr-Al alloy and (b) Fe-Cr-Al-ODS alloy.

Figure 3 shows the surface $\mathrm{X}$-ray diffraction patterns of the $\mathrm{Fe}-\mathrm{Cr}-\mathrm{Al}$ alloy and $\mathrm{Fe}-\mathrm{Cr}-\mathrm{Al}$ ODS alloy after high-temperature oxidation. The relative intensity of the $\alpha-\mathrm{Al}_{2} \mathrm{O}_{3}$ diffraction peaks in the XRD of the two alloys is the highest, which indicates that the main components of the oxide layer after high-temperature oxidation were $\mathrm{Al}_{2} \mathrm{O}_{3}$. For the Fe-Cr-Al alloy, there was a small amount of $\mathrm{Fe}_{2} \mathrm{O}_{3}$ in the oxide layer. In addition, since XRD penetrates the oxide layer to the matrix, the peak of $\mathrm{FeCr}$ is displayed for the two alloys.

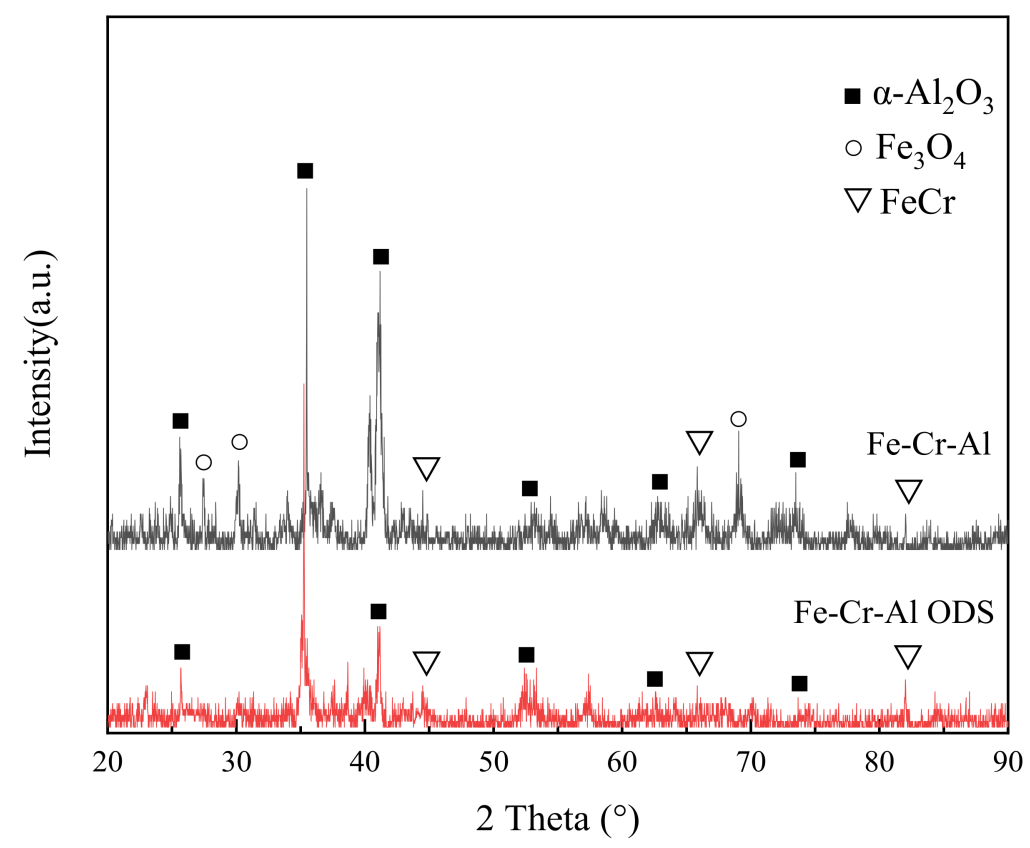

Figure 3. Surface XRD pattern of two alloys after high-temperature oxidation.

Figure $4 \mathrm{a}$,b show cross-sections of the two alloys after oxidation treatments at $1200{ }^{\circ} \mathrm{C}$ for $100 \mathrm{~h}$. The thickness of the oxide layer of the Fe-Cr-Al specimen was obviously thicker than that of the ODS specimen. The oxide layer thicknesses of the two alloys were about 13 and $6 \mu \mathrm{m}$, respectively. Cracks (marked by white arrows) were observed in the oxide layer of the Fe-Cr-Al specimen as shown in Figure 4a, which indicates that $\mathrm{O}$ can pass through these cracks resulting in accelerated oxidation $t$. Upon the addition of $\mathrm{Y}_{2} \mathrm{O}_{3}$ and $\mathrm{Zr}$ in the Fe-Cr-Al alloy, the oxide layer became thinner as shown in Figure $4 \mathrm{~b}$. The EDS-line scans shown in Figure $4 \mathrm{c}, \mathrm{d}$ show that the main elements in the oxide layer were $\mathrm{Al}$ and $\mathrm{O}$. This suggests the presence of alumina scale on each alloy. In addition, for the Fe-Cr-Al specimen, the matrix near the oxide layer had a lower Al content. 

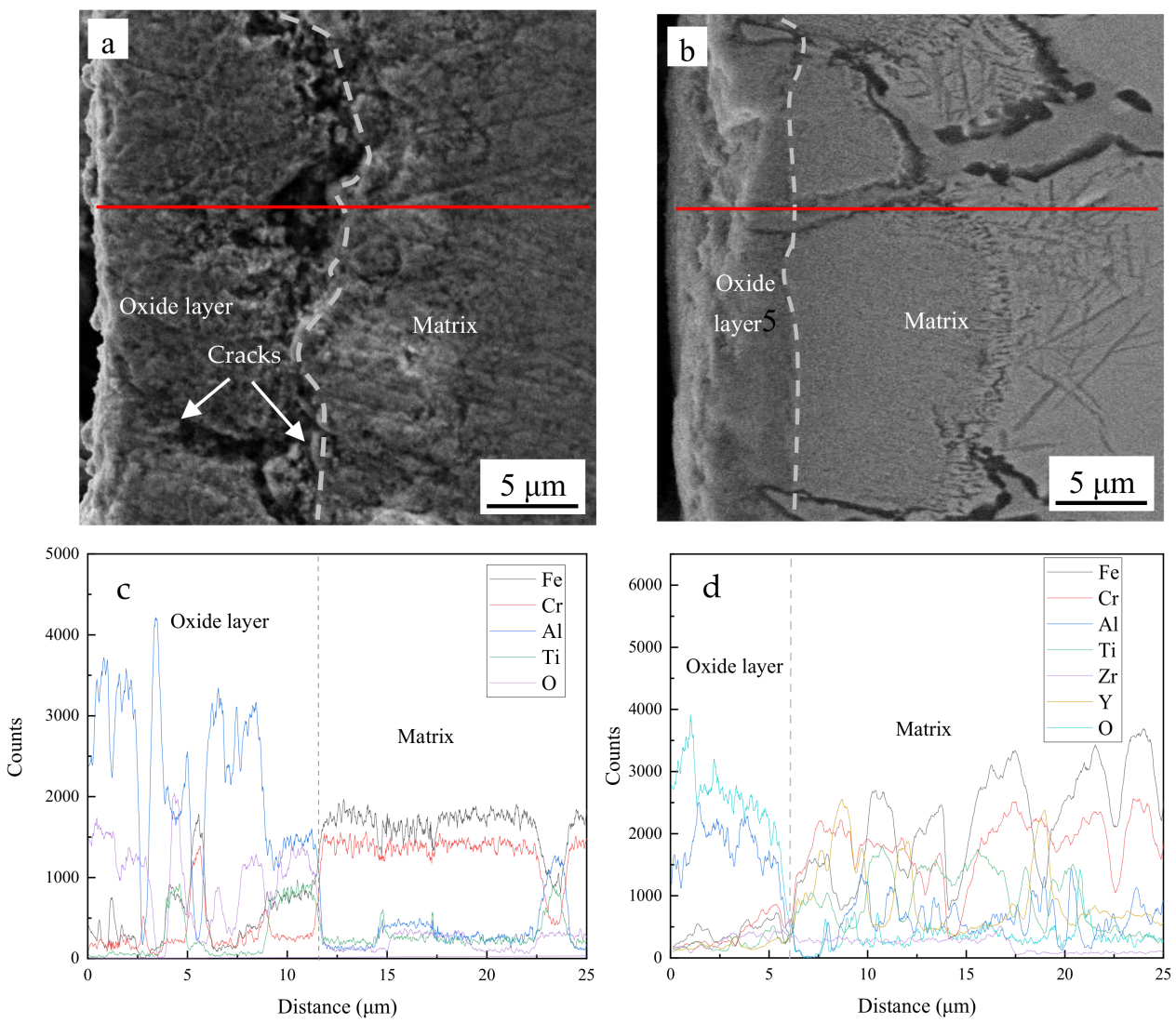

Figure 4. SEM and EDS line of Fe-Cr-Al specimen (a,c), and Fe-Cr-Al ODS specimen (b,d).

\subsection{Microstructural Evolution}

Figure 5 shows the EBSD patterns of the grains of the $\mathrm{Fe}-\mathrm{Cr}-\mathrm{Al}$ alloy and $\mathrm{Fe}-\mathrm{Cr}-\mathrm{Al}$ ODS alloy and their high-temperature oxidation samples. As shown in Figure 5a,c, the two alloys prepared by SPS displayed fine and uniform grains. After high-temperature oxidation, the grains of the two alloys were coarsened. However, whether before or after high-temperature oxidation, the grain size of the Fe-Cr-Al ODS alloy (from 0.33 to $4.42 \mu \mathrm{m}$ ) was smaller than that of the $\mathrm{Fe}-\mathrm{Cr}-\mathrm{Al}$ alloy (from 1.03 to $10.16 \mu \mathrm{m}$ ) due to the nano-oxides.

Figure 6 shows the TEM images of the nano-oxides near the surface in the Fe-Cr-Al ODS alloy matrix before and after high-temperature oxidation. As can be seen from the Figure 6 that the coarsening of these nanoparticles is limited after long exposure times at $1200{ }^{\circ} \mathrm{C}$, which indicates that the nanoparticles have excellent thermal stability. As Figure $6 \mathrm{c}$, d show, the average sizes of the oxides in the Fe-Cr-Al ODS specimens before and after high-temperature oxidation were about 6.7 and $11.3 \mathrm{~nm}$, respectively. 

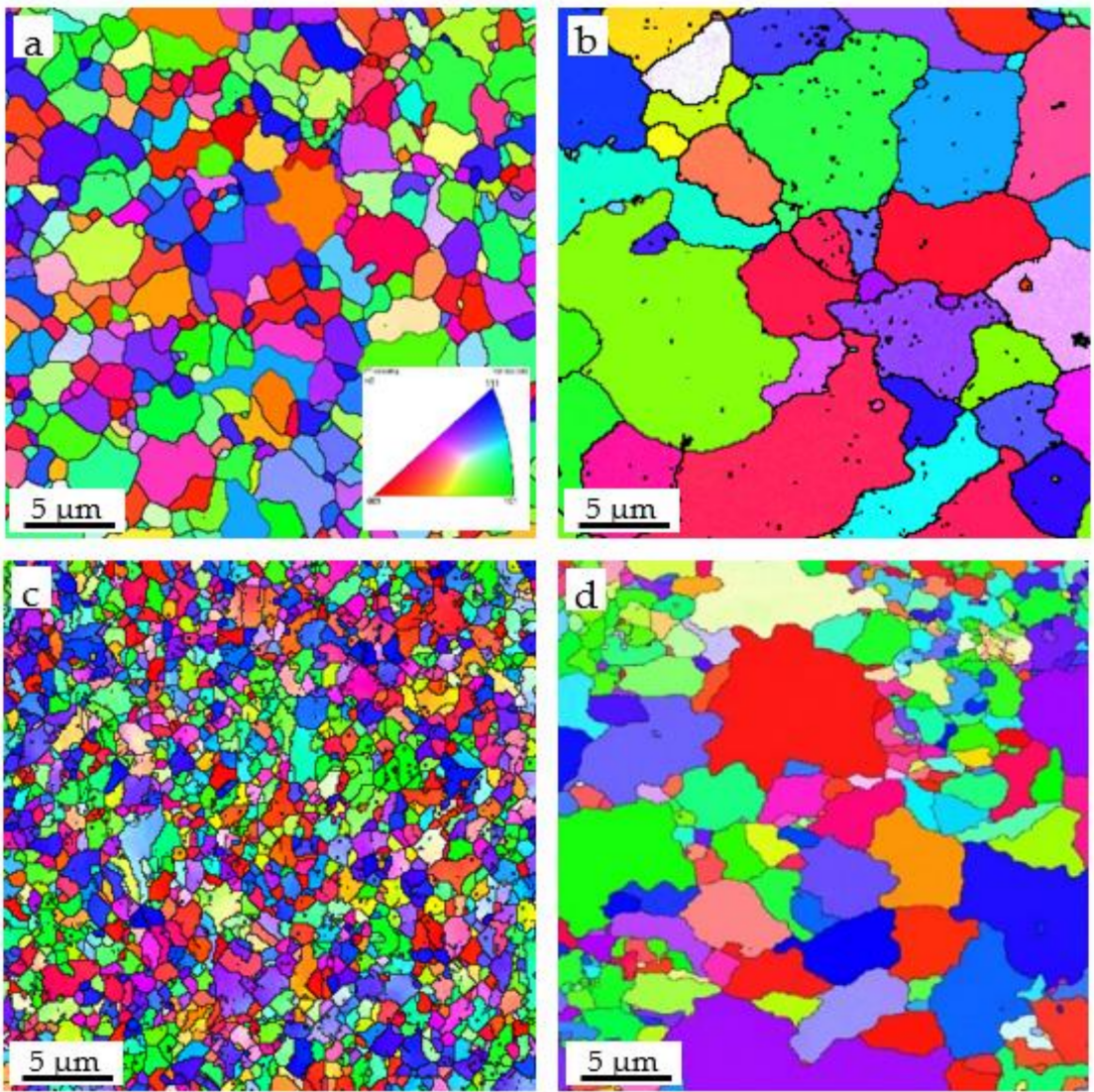

Figure 5. Electron backscattered diffraction (EBSD) analyses of the Fe-Cr-Al specimen before (a) and after (b) high-temperature oxidation, and Fe-Cr-Al ODS specimen before (c) and after (d) hightemperature oxidation.
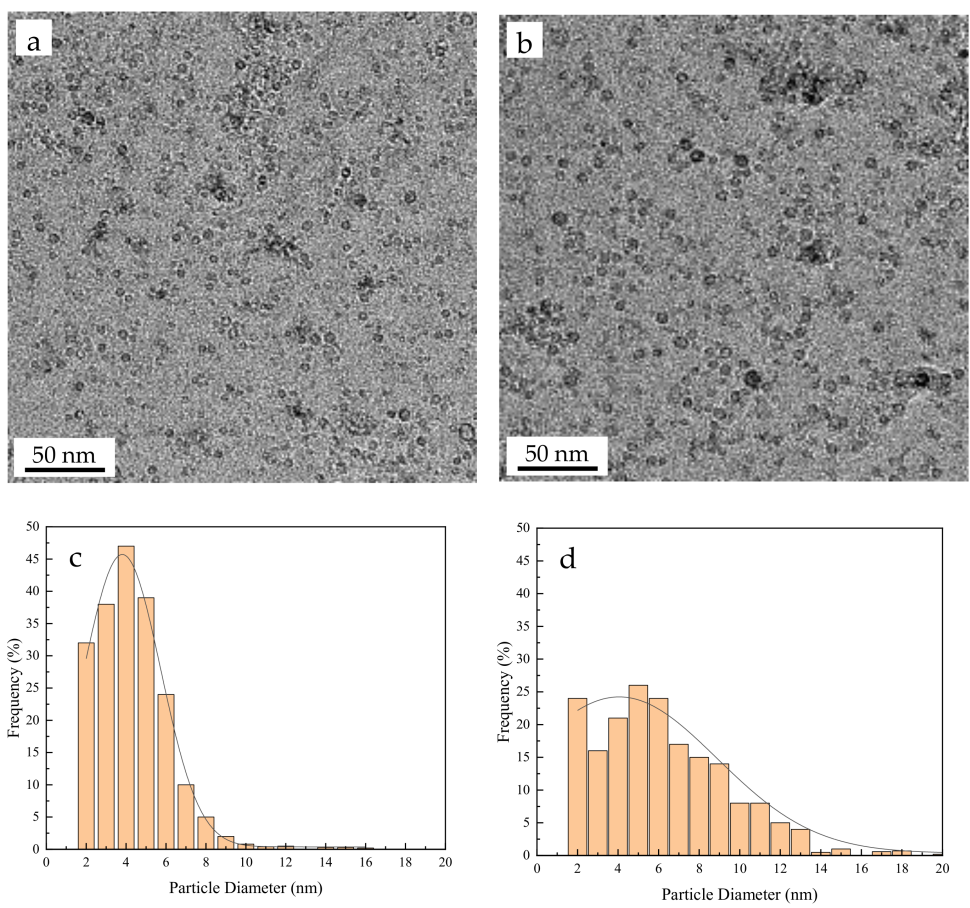

Figure 6. TEM views of nano-oxide particles and their size distributions in Fe-Cr-Al ODS alloys: before $(\mathbf{a}, \mathbf{c})$ high-temperature and $\operatorname{after}(\mathbf{b}, \mathbf{d})$ high-temperature oxidation. 


\section{Discussion}

When the oxidation reaches steady state, the reaction behavior follows the parabolic rule, and the growth rate of the oxide layer is given by [23]:

$$
k_{p}=x^{2} / t
$$

where $k_{p}$ is the parabolic oxidation rate, $x$ is the mass gain for each specimen in air and $t$ is the oxidation time. The parabolic oxidation rate $k_{p}$ with time curves are shown in Figure 7. The parabolic oxidation rate was extremely high at the initial stage of the hightemperature oxidation, indicating that the oxidation reaction was very intense. As the oxide film became thicker, it protected the matrix, and the oxidation rate decreased. After $30 \mathrm{~h}$ of high-temperature oxidation, the oxidation rate tended to stabilize. However, the parabolic oxidation rate of the $\mathrm{Fe}-\mathrm{Cr}-\mathrm{Al}$ specimen was much higher than that of the $\mathrm{Fe}-\mathrm{Cr}-\mathrm{Al}$ ODS specimen.

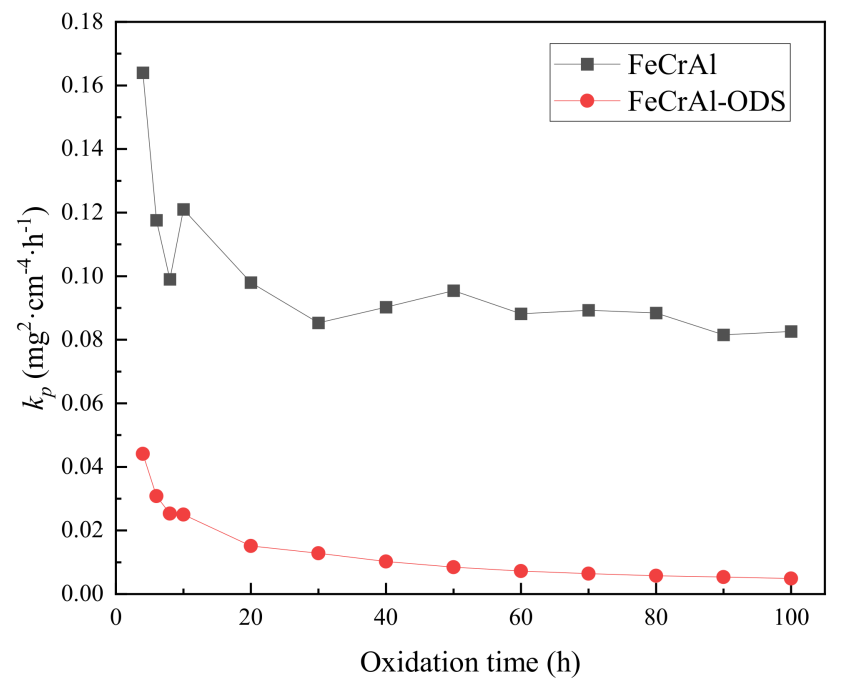

Figure 7. Parabolic oxidation rate $k_{p}$ with time curves.

The thickness of the oxide scale increases faster in the early stage of oxidation due to the faster oxidation rate. The mass change during initial high-temperature oxidation is expressed as [24]:

$$
\begin{gathered}
2 \mathrm{Al}(\mathrm{s})+3 / 2 \mathrm{O}_{2}(\mathrm{~g})-\mathrm{Al}_{2} \mathrm{O}_{3}(\mathrm{~s}) \\
2 \mathrm{Cr}(\mathrm{s})+3 / 2 \mathrm{O}_{2}(\mathrm{~g})-\mathrm{Cr}_{2} \mathrm{O}_{3}(\mathrm{~s}) \\
3 \mathrm{Fe}(\mathrm{s})+2 \mathrm{O}_{2}(\mathrm{~g})-\mathrm{Fe}_{3} \mathrm{O}_{4}(\mathrm{~s})
\end{gathered}
$$

As the oxidation progresses, the reaction can be expressed as:

$$
\begin{gathered}
2 \mathrm{Al}+3 / 4 \mathrm{Fe}_{3} \mathrm{O}_{4}-\mathrm{Al}_{2} \mathrm{O}_{3}+9 / 4 \mathrm{Fe} \\
2 \mathrm{Al}+\mathrm{Cr}_{2} \mathrm{O}_{3}-\mathrm{Al}_{2} \mathrm{O}_{3}+2 \mathrm{Cr}
\end{gathered}
$$

As Equation (2) to Equation (6) show, the growth of the oxide scale requires the continuous diffusion of $\mathrm{Al}$ and $\mathrm{O}$. It is generally believed that the elements are more likely to diffuse in defects (vacancies and cracks) and grain boundaries [25-27]. As Figures 2 and 4 show, the oxide scale of the Fe-Cr-Al specimen was more dense and thicker, and there were more cracks and porosity than in the Fe-Cr-Al ODS specimen. This is because the rapid oxidation reaction made the oxide scale looser and produced a lot of holes. The metal oxide scale usually has a different expansion coefficient from the alloy matrix. When the temperature changes, the oxide film cracks under the action of thermal tension [28]. This makes it easier for $\mathrm{O}_{2}$ to diffuse into the matrix. This resulted in a peak in the oxidation rate 
curve of the $\mathrm{Fe}-\mathrm{Cr}-\mathrm{Al}$ alloy after $8 \mathrm{~h}$. In addition, the rapid oxidation reaction consumed a large amount of $\mathrm{Al}$ element, resulting in the formation of areas with low $\mathrm{Al}$ content (as shown in Figure 4c) and a lot of vacancies in the alloy near the oxide scale [29]. As the oxidation reaction progresses, the difference in plastic deformation and the accumulation of vacancies lead to the creation of a fold $[26,28]$.

For Fe-Cr-Al ODS alloys, the grain size is smaller and there are more grain boundaries, as Figure 5 shows; however, the high-density and dispersed nano-oxides can hinder the diffusion of Al. This makes the growth rate of the oxide film not too fast at the beginning of the oxidation, which makes the oxide film denser and enhances the force of bonding with the alloy matrix.

In addition, during the oxidation process for $100 \mathrm{~h}$ at $1200{ }^{\circ} \mathrm{C}$, the grain sizes of the Fe-Cr-Al alloy and Fe-Cr-Al ODS alloy increased by 9.13 and $4.09 \mu \mathrm{m}$, respectively. Additionally, the size of the nano-oxide in the Fe-Cr-Al ODS alloy was coarsened by $68.7 \%$ (from 6.7 to $11.3 \mathrm{~nm}$ ). Table 2 shows the grain size and nano-oxide density, average diameter and volume fraction before and after the oxidation of the Fe-Cr-Al alloy and Fe-Cr-Al ODS alloy. During high-temperature oxidation, high-density nano-oxide hinders the growth of alloy grains due to pinning the grain boundaries [22], and at the same time, it can also prevent the formation of voids by eliminating vacancies at the interface between the internal oxide particles and the matrix $[22,30,31]$. A schematic illustration of the mechanism of high-temperature oxidation for the two alloys is shown in Figure 8. The black dots in the figure correspond to the Y-rich nano-oxide of the ODS alloy.

Table 2. Grain size and nano-oxide density, average diameter and volume fraction before and after oxidation of $\mathrm{Fe}-\mathrm{Cr}-\mathrm{Al}$ alloy and Fe-Cr-Al-ODS alloy.

\begin{tabular}{ccccc}
\hline Material & $\begin{array}{c}\text { Average Grain } \\
\text { Size/ } \mathbf{\mu m}\end{array}$ & $\begin{array}{c}\text { Number Density } \\
\text { of Particles/m }\end{array}$ & $\begin{array}{c}\text { Average Particle } \\
\text { Diameter/nm }\end{array}$ & $\begin{array}{c}\text { Volume Fraction of } \\
\text { Particles/\% }\end{array}$ \\
\hline Fe-Cr-Al (before oxidation) & 1.03 & - & - & - \\
Fe-Cr-Al (after oxidation) & 10.16 & - & - & - \\
Fe-Cr-Al ODS (before oxidation) & 0.33 & $3.9 \times 10^{22}$ & 6.7 & 0.73 \\
Fe-Cr-Al ODS (after oxidation) & 4.42 & $0.66 \times 10^{22}$ & 11.3 & 0.98 \\
\hline
\end{tabular}
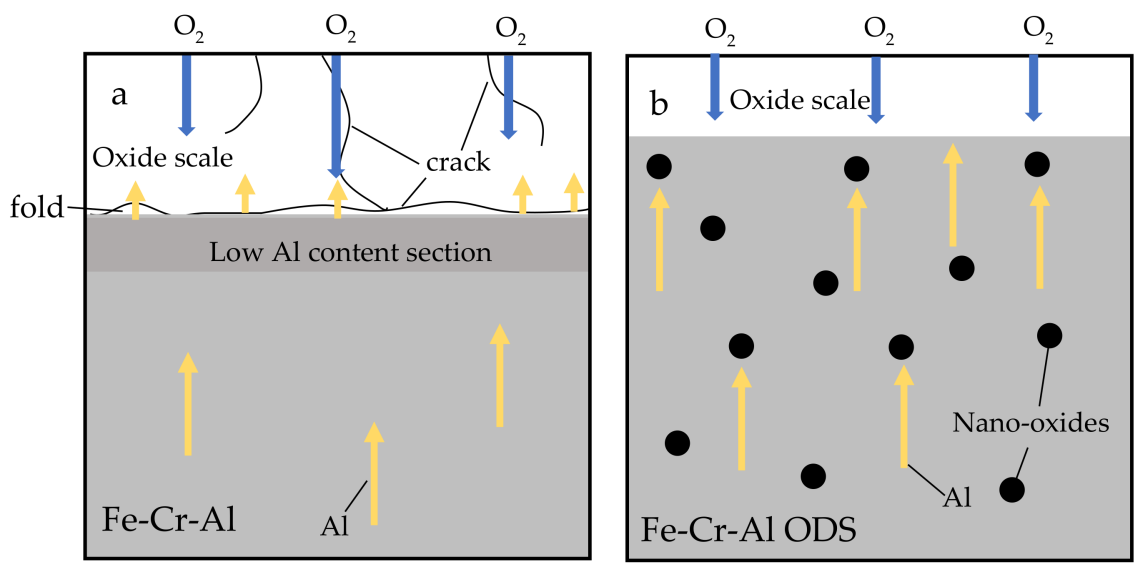

Figure 8. Schematic illustration of mechanism of high-temperature oxidation: (a) Fe-Cr-Al alloy and (b) Fe-Cr-Al ODS alloy.

\section{Conclusions}

High-temperature oxidation experiments were performed to investigate the oxidation behavior and microstructural evolution of the nanostructure of Fe-Cr-Al ODS alloys prepared by spark plasma sintering. The results obtained are summarized as follows:

1. Although only one sample was measured, the oxidation rate of Fe-Cr-Al ODS alloys is obviously lower than that of $\mathrm{Fe}-\mathrm{Cr}$ - $\mathrm{Al}$ alloys, and the oxide layer formed on the 
Fe-Cr-Al alloy appeared loose and cracked, whereas the oxide layer formed on the Fe-Cr-Al ODS alloys was adherent and flat.

2. The main components of the oxide layers of the two alloys are $\mathrm{Al}_{2} \mathrm{O}_{3}$. However, due to the existence of voids and cracks in the oxide layer in the Fe-Cr-Al alloys, a small amount of iron oxide was contained in the oxide layer.

3. Due to the pinning effect of nano-oxide, the Fe-Cr-Al ODS alloy exhibited excellent high-temperature stability. This shows that the formation of nano-oxides can not only increase the strength, but also improve the high-temperature oxidation performance.

Author Contributions: Conceptualization, Z.L.; methodology and validation, L.C.; formal analysis, Z.L.; investigation, Z.L.; resources, L.C.; data curation, Z.L. and H.Z.; writing-original draft preparation, Z.L. and L.C.; writing-review and editing, L.C. and Z.L.; visualization, Z.L.; data collection S.L.; supervision and funding acquisition, H.Z. All authors have read and agreed to the published version of the manuscript.

Funding: This work was financially supported by the Foundation of the State Key Laboratory of Rolling and Automation, Northeastern University (2018RALKFKT010).

Institutional Review Board Statement: This study does not involve human or animal.

Informed Consent Statement: This study does not involve human.

Data Availability Statement: Restrictions apply to the availability of these data. Data was obtained from Northeast University and Shenyang University of Technology and are available from the authors with the permission of Northeast University and Shenyang University of Technology.

Conflicts of Interest: The authors declare no conflict of interest.

\section{References}

1. Terrani, K.A. Accident tolerant fuel cladding development: Promise, status, and challenges. J. Nucl. Mater. 2018, 501, 13-30.

2. Yamamoto, Y.; Pint, B.A.; Terrani, K.A.; Field, K.G.; Yang, Y.; Snead, L.L. Development and property evaluation of nuclear grade wrought FeCrAl fuel cladding for light water reactors. J. Nucl. Mater. 2015, 467, 703-716.

3. Pint, B.A.; Terrani, K.A.; Yamamoto, Y.; Snead, L.L. Material Selection for Accident Tolerant Fuel Cladding. Metall. Mater. Trans. E 2015, 2, 190-196.

4. Rebak, R.B.; Gupta, V.K.; Larsen, M. Oxidation Characteristics of Two FeCrAl Alloys in Air and Steam from $800{ }^{\circ} \mathrm{C}$ to $1300{ }^{\circ} \mathrm{C}$. JOM 2018, 70, 1484-1492.

5. Kimura, A.; Kasada, R.; Iwata, N.; Kishimoto, H.; Zhang, C.H.; Isselin, J.; Dou, P.; Lee, J.H.; Muthukumar, N.; Okuda, T.; et al. Development of $\mathrm{Al}$ added high-Cr ODS steels for fuel cladding of next generation nuclear systems. J. Nucl. Mater. 2011, 417, 176-179.

6. Cho, H.S.; Kimura, A.; Ukai, S.; Fujiwara, M. Corrosion properties of oxide dispersion strengthened steels in super-critical water environment. J. Nucl. Mater. 2004, 329, 387-391.

7. Alamo, A.; Lambard, V.; Averty, X.; Mathon, M.H. Assessment of ODS-14\%Cr ferritic alloy for high temperature applications. J. Nucl. Mater. 2004, 329, 333-337.

8. Götlind, H.; Liu, F.; Svensson, J.E.; Halvarsson, M.; Johansson, L.G. The Effect of Water Vapor on the Initial Stages of Oxidation of the FeCrAl Alloy Kanthal AF at $900{ }^{\circ} \mathrm{C}$. Oxid. Met. 2007, 67, 251-266.

9. Chen, H.-Z.; Li, B.-R.; Wen, B.; Ye, Q.; Zhang, N.-Q. Corrosion resistance of iron-chromium-aluminium steel in eutectic molten salts under thermal cycling conditions. Corrosion Sci. 2020, 173, 108798.

10. Dömstedt, P.; Lundberg, M.; Szakálos, P. Corrosion studies of a low alloyed Fe-10Cr-4Al steel exposed in liquid Pb at very high temperatures. J. Nucl. Mater. 2020, 531, 152022.

11. Pimentel, G.; Chao, J.; Capdevila, C. Recrystallization Process in Fe-Cr-Al Oxide Dispersion-Strengthened Alloy: Microstructural Evolution and Recrystallization Mechanism. JOM 2014, 66, 780-792.

12. Massey, C.P.; Edmondson, P.D.; Unocic, K.A.; Yang, Y.; Dryepondt, S.N.; Kini, A.; Gault, B.; Terrani, K.A.; Zinkle, S.J. The effect of $\mathrm{Zr}$ on precipitation in oxide dispersion strengthened FeCrAl alloys. J. Nucl. Mater. 2020, 533, 152105.

13. Unocic, K.A.; Pint, B.A.; Hoelzer, D.T. Advanced TEM characterization of oxide nanoparticles in ODS Fe-12Cr-5Al alloys. J. Mater. Sci. 2016, 51, 9190-9206.

14. Ren, J.; Yu, L.; Liu, Y.; Liu, C.; Li, H.; Wu, J. Effects of Zr Addition on Strengthening Mechanisms of Al-Alloyed High-Cr ODS Steels. Materials 2018, 11, 118.

15. Unocic, K.A.; Essuman, E.; Dryepondt, S.; Pint, B.A. Effect of environment on the scale formed on oxide dispersion strengthened $\mathrm{FeCrAl}$ at $1050^{\circ} \mathrm{C}$ and $1100^{\circ} \mathrm{C}$. Mater. High Temp. 2014, 29, 171-180. 
16. Unocic, K.A.; Yamamoto, Y.; Pint, B.A. Effect of Al and Cr Content on Air and Steam Oxidation of FeCrAl Alloys and Commercial APMT Alloy. Oxid. Met. 2017, 87, 431-441.

17. Merceron, G.; Molins, R.; Strudel, J.-L. Oxidation behaviour and microstructural evolution of FeCrAl ODS alloys at high temperature. Mater. High Temp. 2014, 17, 149-157.

18. Lipkina, K.; Hallatt, D.; Geiger, E.; Fitzpatrick, B.W.N.; Sakamoto, K.; Shibata, H.; Piro, M.H.A. A study of the oxidation behaviour of FeCrAl-ODS in air and steam environments up to $1400^{\circ} \mathrm{C}$. J. Nucl. Mater. 2020, 541, 152305.

19. Maeda, T.; Ukai, S.; Hayashi, S.; Oono, N.; Shizukawa, Y.; Sakamoto, K. Effects of zirconium and oxygen on the oxidation of FeCrAl-ODS alloys under air and steam conditions up to $1500{ }^{\circ} \mathrm{C}$. J. Nucl. Mater. 2019, 516, 317-326.

20. Li, Z.; Chen, L.; Zhang, H.; Zhang, S.; Zhang, Z.; Liu, S. Effect of Hot Rolling on the Microstructure and Properties of Nanostructured 15Cr ODS Alloys with Al and Zr Addition. Materials 2020, 13, 3695.

21. Li, Z.; Lu, Z.; Xie, R.; Lu, C.; Liu, C. Effect of spark plasma sintering temperature on microstructure and mechanical properties of 14Cr-ODS ferritic steels. Mater. Sci. Eng. A 2016, 660, 52-60. [CrossRef]

22. Li, Z.; Chen, L.; Zhang, H.; Zhang, S.; Zhang, Z. Effect of annealing temperature on microstructure and mechanical properties in oxide dispersion strengthened Fe-14Cr alloys prepared by spark plasma sintering. Mater. Res. Express 2019, 6, 126515. [CrossRef]

23. Pieraggi, B. Calculations of parabolic reaction rate constants. Oxid. Met. 1987, 27, 177-185. [CrossRef]

24. Fabrichnaya, O.; Seifert, H.J.; Ludwig, T.; Aldinger, F.; Navrotsky, A. The assessment of thermodynamic parameters in the $\mathrm{Al} 2 \mathrm{O}$ 3-Y $2 \mathrm{O}$ 3system and phase relations in the Y-Al-O system. Scand. J. Metall. 2002, 30, 175-183. [CrossRef]

25. Dong, Q.; Hultquist, G.; Sproule, G.I.; Graham, M.J. Platinum-catalyzed high temperature oxidation of metals. Corrosion Sci. 2007, 49, 3348-3360. [CrossRef]

26. Pan, D.; Zhang, R.; Wang, H.; Lu, C.; Liu, Y. Formation and stability of oxide layer in FeCrAl fuel cladding material under high-temperature steam. J. Alloys Compd. 2016, 684, 549-555. [CrossRef]

27. Ali, A.F.; Gorton, J.P.; Brown, N.R.; Terrani, K.A.; Jensen, C.B.; Lee, Y.; Blandford, E.D. Surface wettability and pool boiling Critical Heat Flux of Accident Tolerant Fuel cladding-FeCrAl alloys. Nucl. Eng. Des. 2018, 338, 218-231. [CrossRef]

28. Evans, H.E. Stress effects in high temperature oxidation of metals. Int. Mater. Rev. 2013, 40, 1-40. [CrossRef]

29. Qiao, Y.; Wang, P.; Qi, W.; Du, S.; Liu, Z.; Meng, F.; Zhang, X.; Wang, K.; Li, Q.; Yao, Z.; et al. Mechanism of Al on FeCrAl steam oxidation behavior and molecular dynamics simulations. J. Alloys Compd. 2020, 828, 154310. [CrossRef]

30. Kaito, T.; Narita, T.; Ukai, S.; Matsuda, Y. High temperature oxidation behavior of ODS steels. J. Nucl. Mater. 2004, 329-333, 1388-1392. [CrossRef]

31. Ju, J.; Yang, C.; Ma, S.; Kang, M.; Wang, K.; Li, J.; Fu, H.; Wang, J. Effect of temperature on oxidation resistance and isothermal oxidation mechanism of novel wear-resistant Fe-Cr-B-Al-C-Mn-Si alloy. Corrosion Sci. 2020, 170, 108620. [CrossRef] 